\title{
The Ecology of Welfare
}

Housing and the Welfare Crisis in

New York City

George S. Sternlieb \& Bernard P. Indik 


\section{THE ECOLOGY OF WELFARE}




\section{URBAN STUDIES SERIES}

General Editor: George S. Sternlieb

The Affluent Suburb: Princeton by George S. Sternlieb, Robert William Burchell and Lynne Beyer Sagalyn

The Zone of Emergence: A Case Study of Plainfield, New Jersey by George S. Sternlieb and W. Patrick Beaton

The Ecology of Welfare: Housing and the Welfare Crisis in New York City by George S. Sternlieb and Bernard P. Indik.

Landlords and Tenants: A Complete Guide to the Residential Rental Relationship by Jerome G. Rose.

555 Families. A Social Psychological Study of Young Families in Transition by Ludwig L. Geismar. 


\title{
THE ECOLOGY OF WELFARE Housing and the Welfare Crisis in New York City
}

\author{
GEORGE S. STERNLIEB \\ Professor of Urban Planning \\ and Director of the Center for Urban Policy Research \\ Livingston College, Rutgers University \\ BERNARD P. INDIK \\ Professor of Social Work \\ Graduate School of Social Work \\ Rutgers University
}

with Mildred Barry and staff

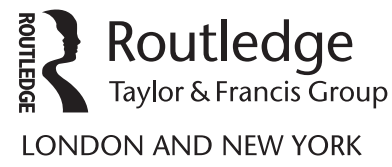


First published 1973 by Transaction Publishers

\author{
Published 2017 by Routledge \\ 2 Park Square, Milton Park, Abingdon, Oxon OX14 4RN \\ 711 Third Avenue, New York, NY 10017
}
Routledge is an imprint of the Taylor and Francis Group, an informa business

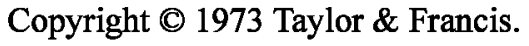

\begin{abstract}
All rights reserved. No part of this book may be reprinted or reproduced or utilised in any form or by any electronic, mechanical, or other means, now known or hereafter invented, including photocopying and recording, or in any information storage or retrieval system, without permission in writing from the publishers.
\end{abstract}

\section{Notice:}

Product or corporate names may be trademarks or registered trademarks, and are used only for identification and explanation without intent to infringe.

Library of Congress Catalog Number: LC-72-82193

This volume was prepared for the Center for Urban Policy Research

Rutger - the State University, New Brunswick, New Jersey

ISBN 13: 978-0-87855-041-8 (hbk) 


\section{CONTENTS}

Acknowledgements $\quad$ xi

Preface xiii

Chapter 1

SOME PARAMETERS OF WELFARE 1

The Growth of Welfare 4

Employment Opportunities and Welfare $\quad 6$

Background of the Study 10

Housing's Linkage to Social Trauma 11

Chapter 2

METHODOLOGY 15

The Attitudes of Welfare Recipients 17

The Probability Sample 18

Variations in Welfare Category 19

Who Was Interviewed 25

Chapter 3

WHO ARE THE WELFARE RECIPIENTS 27

Length of Residence 27

Place of Origin $\quad 29$

Reasons for Moving 31

Characteristics of Welfare Recipients

Race 33

Age $\quad 37$

Household size $\quad 37$

Children under ten $\quad 39$

Children ten to eighteen $\quad 43$

Education 45

Marital status $\quad 46$

Employment and employability $\quad 47$ 


\section{Chapter 4}

THE WELFARE RECIPIENT'S HOUSING 53

Type of Housing 54

Juridical Status 55

Quality of Housing 56

Age and configuration $\quad 59$

Ethnic Segregation Patterns 63

Welfare Category $\quad 64$

Shifts in Welfare Density 67

The Use of Hotels 68

The law of large numbers $\quad 69$

The Role of Public Housing $\quad 70$

Ethnicity in public housing 71

The future use of public housing $\quad 72$

Interior Maintenance of Housing $\quad 73$

Ethnicity 77

Welfare category $\quad 77$

Borough variation $\quad 77$

Violations $\quad 77$

Crowding 79

Overcrowding by ethnicity 80

Housing Mobility Patterns $\quad 82$

Borough patterns $\quad 82$

Mobility versus ethnicity $\quad 83$

Intent to move 83

Search Patterns in Housing $\quad 85$

Ethnicity 87

Use of the Services in Housing 99

Ethnic patterns $\quad 92$

Type of assistance received $\quad 92$

Summary $\quad 93$

Chapter 5

THE WELFARE RECIPIENTS' ATTITUDE

TOWARD HIS HOUSING AND ITS SETTING 99

The Problem of Standards $\quad 99$

Satisfaction with Present Accomodations 102

Satisfaction level by ethnicity 102

Borough variations 105

Reasons for Satisfaction and Dissatisfaction 105

Satisfaction with Apartment Amenities $\quad 110$

Aspirations for Better Housing $\quad 110$ 


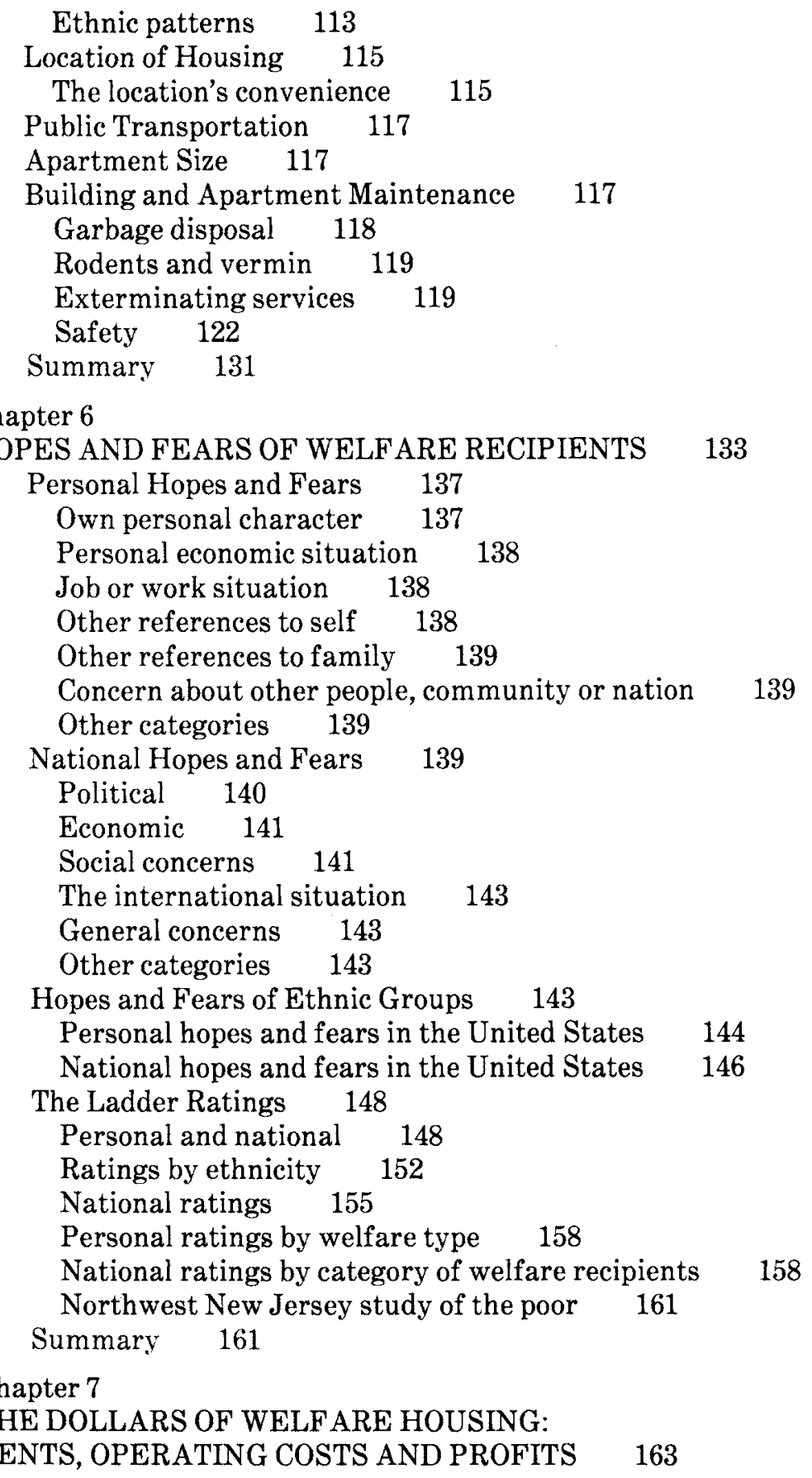


Rent Paid by Welfare Recipients 164

Welfare rents in New York 165

Do welfare recipients pay more? 173

Ownership of Welfare Buildings 175

Length of time in business 178

Reasons for purchase $\quad 178$

Reasons for keeping the property $\quad 180$

Scale of holdings 182

Owner ethnicity 184

Profitability of Welfare Housing 186

Expenses 187

Repair costs $\quad 189$

Operating profits 192

Cash flow 195

Net taxable income $\quad 197$

Summary 197

Chapter 8

FINANCING THE REHABILITATION

OF WELFARE HOUSING 201

The Gap Between Gross Rents and Net Rents 202 Using current real estate taxes 204

Mortgageability and debt service 205

Debt service 206

Adequacy of Institutional Financing $\quad 210$

Depreciation 211

Chapter 9

POLICY IMPLICATIONS 215

Evaluation of Apartment Quality $\quad 217$

Plans for the Future and Housing Satisfaction $\quad 221$

\section{APPENDICES}

Appendix 1.1

Memorandum on Trends in AFDC Benefit Levels $\quad 229$

Appendix 1.2

Categories of Welfare 233

Appendix 2.1

Interview Forms $\quad 239$

Appendix 3.1

Characteristics of Households with Children 253

Appendix 4.1

The Furnished Apartment Dweller $\quad 259$ 
Appendix 5.1

The Semantic Differential 265

Appendix 6.1

The Cantril Self-Anchoring Striving Scale $\quad 277$

Appendix 6.2

The Complete Cantril Code 281 


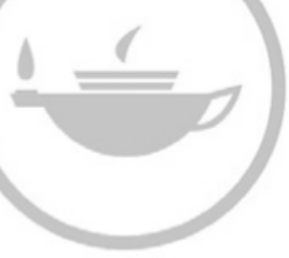

Taylor \& Francis Taylor \& Francis Group http://taylorandfrancis.com 


\section{ACKNOWLEDGEMENTS}

This study was made possible only by the aid of the over 400 welfare recipients and their families who gave us their cooperation. Though we could give them no hope of future reward, with very few exceptions, they were greatly receptive to interviewers and tried to be helpful in what at best was a complex and lengthy procedure.

One of the strongest feelings that we take with us from the study is the variation between the myth of the professional welfare recipient and the reality of so many people blunted by the vagaries of life and illfortune but still trying to make a reasonable life within a society with all too many barriers. Our gratitude for the positive partnership that was established between our staff and the respondents is substantial.

More than 40 people from the staff of the Center for Urban Policy Research worked on this project with great cheerfulness and enterprise. This study would have been impossible without their efforts. Mildred Barry did yeoman work in creatively administering the field interviewing staff. Audrey Greene was in charge of the video-taped group interviews and provided an unobtrusive but highly imaginative and productive format for them. Dominic Salluce together with Mary Picarella kept track of what at times seemed practically an overwhelming flood of data.

Our colleagues, Professors Ludwig Geismar, Ben Ami Gelin and Audrey Faulkner, provided most useful criticisms of the original manuscript. Glen Margo, together with William Dolphin, took much responsibility for the orderly execution of the machine computation and 
analysis. Mary Curtis and J. Carl Cook performed nobly in editing a very unwieldy manuscript. The errors that remain are the authors' own.

The cooperation received from the Department of Social Services of the Human Resources Administration was admirable. We are most grateful for it.

Funding for this study was secured through the Ford Foundation through the aegis of Dr. Louis Winnick and William C. Pendleton. Both of them made many helpful comments in criticisms of the literary presentation.

Large-scale efforts involved large-scale obligations. It is indeed a pleasure to express our gratitude to all the participants in the study. 


\section{PREFACE}

The interplay between housing and outlook, between the physical attributes of a dwelling unit and the attitudes and responses of its inhabitants, are areas that have been subject to more ritual than research. Optimizing the mix of social inputs is still a goal rather than a reality. We measure the effectiveness of our social and economic programs by what we want to see or to happen rather than by what their consequences really are for the people involved. The relationship between the distribution of human groups with reference to material resources and the consequent social and cultural patterns that evolve from this distribution, i.e., their basic ecology, is just beginning to get large-scale, orderly attention.

This book is dedicated to one such human group-the welfare recipients of New York City. Attention to these people has long been the province of professional social workers and charitable groups, with an occasional input by irate taxpayers and municipal officials. In our own time, however, the sheer growth in the number of welfare recipients has changed this. A glance at the pages of any of the major newspapers or current events magazines indicates the extent of popular concern about the distribution of welfare monies: compare the multiple pages given over to welfare in the New York Times Index for 1972, with the paucity of equivalent entries a brief ten years earlier. As yet, most of this attention has come in the form of a set of a priori assertions-"They're all a bunch of con artists taking advantage of the system"-or sentiments to the effect that the expansion of the welfare rolls is a symbol of injustice 
generated by our entire socioeconomic system. Too often lost in this barrage of assertions are the people on welfare, where they live, what they want, like and fear and perhaps as much as anything else, just who they are. Overlooked in the statistics of $\mathrm{X}$ proportion of ADC mothers or $\mathrm{Y}$ proportion of the elderly, are the people themselves. Certainly statistical anonymity is not unique to welfare recipients; it all too frequently neutralizes the life styles of other groups in our society. The sheer fragility, however, of the welfare recipients' lives, the very specific and unique response to them of other groups in society-landlords and grocers, city officials and social workers-make much more knowledge and insight an absolute necessity.

Housing may be a major area of governmental input and support of the poor, perhaps as much because money spent on housing is easily accounted for and provides tangible results as because of its real impact on the lives and life styles of its beneficiaries. Housing lends itself to statistics about the number of structures erected, the proportion of dwelling units rehabilitated and the like. It can be seen as well as counted in contrast with many alternative social inputs. How do welfare recipients view their present housing accommodations? What would they like? What are their hopes and fears for the future, and what do these mean in terms of support systems? These are essential questions-for which there are no easily ascertainable answers.

The study that follows attempts to provide some insight into these questions. It has all of the limitations of the social sciences compounded by those of the authors. We hope, however, that if nothing more, The Ecology of Welfare will encourage more sophisticated future research along the lines developed herein. 


\section{Chapter 1}

\section{SOME PARAMETERS OF WELFARE}

Public thinking in America has historically conceived of welfare recipients as atypical-including the old, the physically disabled and perhaps a small number of temporarily unemployed. The absolute expansion of numbers on welfare that has occurred in recent years has therefore found the majority of voters as well as many of their leaders looking to solutions which have been outpaced by the scale and complexity of the welfare phenomenon.

The increase of dependency in the North was initially viewed as resulting from the sudden influx of rural poor from the South and from Puerto Rico. The problem, therefore, was held to be transitional and was to be resolved by the acculturation of rural displacees. Novels of a generation ago are replete with anecdotal material describing the problems of adjustment to urban living. A search through that literature reveals many variations on the theme. Probably the most famous was John Steinbeck's The Grapes of Wrath, the odyssey of agricultural displacees who, at one point for example, find themselves completely baffled by the intricacies of modern-day plumbing.

As the tidal wave of rural migration has declined, however, some of the harsh facts are becoming more apparent. First, the number of recipients is continuing to grow in absolute terms. By June 1970, 6 percent of the United States population was receiving money payments under public assistance programs. ${ }^{1}$ Second, the expansion in welfare has taken place largely during a period of unparalleled business prosperity. Third, and perhaps most significant, is the increasing proportion of 
welfare payments in relation to local government expenditures.

In the past, the amount and character of welfare payments were seen nearly exclusively as the concern of institutions and government functionaries, of technocrats of various persuasions. Welfare at a time of full employment, however, becomes a substantial and meaningful focus of popular political interest: this is something relatively new.

Is welfare a right or a privilege? Both assertions have been made by responsible parties. The National Welfare Rights Organization has asserted that it is clearly a right, but Supreme Court Judge Blackmun, in the case of Wyman v. James (U.S. 27 L Ed. 2d 408) clearly had in mind the latter description. In his opinion of January 1971 he stated:

One who dispenses purely private charity naturally has an interset in and expects to know how his charitable funds are utilized and put to work. The public, when it is the provider, rightly expects the same. It might well expect more, because of the trust aspect of public funds and the recipient, as well as the caseworker, has not only an interest but an obligation.

Since 1965, it has been argued successfully that public assistance recipients have full First Amendment rights to privacy, that the equal protection clause prohibits different treatment for persons receiving and not receiving welfare, and that welfare benefits are entitlements in the nature of property rights which cannot be taken away or diminished without hearings meeting due process standards; the Supreme Court also declared unconstitutional the "substitute father" rule and residency laws. ${ }^{2}$

Public attitudes toward welfare in the next few years may well depend on the causes and constituents of the welfare population. Certainly, in 1971 a sharply negative public reaction was apparent. Appendix 1.1 indicates the level of state action in the area of welfare, as summarized in a HEW memorandum of July $2,1971$.

What is the future of welfare? It should be noted that the memorandum cited in Appendix 1.2 only accounts for the absolute numbers of individuals on welfare to mid-1970. In the year that followed the number of welfare recipients on a national base continued to grow. By mid1971 it was estimated that 14.4 million Americans were receiving some form of dependency allotment. ${ }^{3}$

Our comparisons in this study will be based on the earlier data because the welfare increase noted there occurred during times of relatively full employment. The increase in unemployment in late 1970-1971 may account for much of the recent growth. At the same time, however, in a number of cities the administration of welfare has become more rigorous, holding down the number of recipients. Unfortunately, we do not have data on these specific and very important variables. 
EXHIBIT 1.1

NUMBER OF PUBLIC ASSISTANCE RECIPIENTS BY PROGRAM ${ }^{a}$

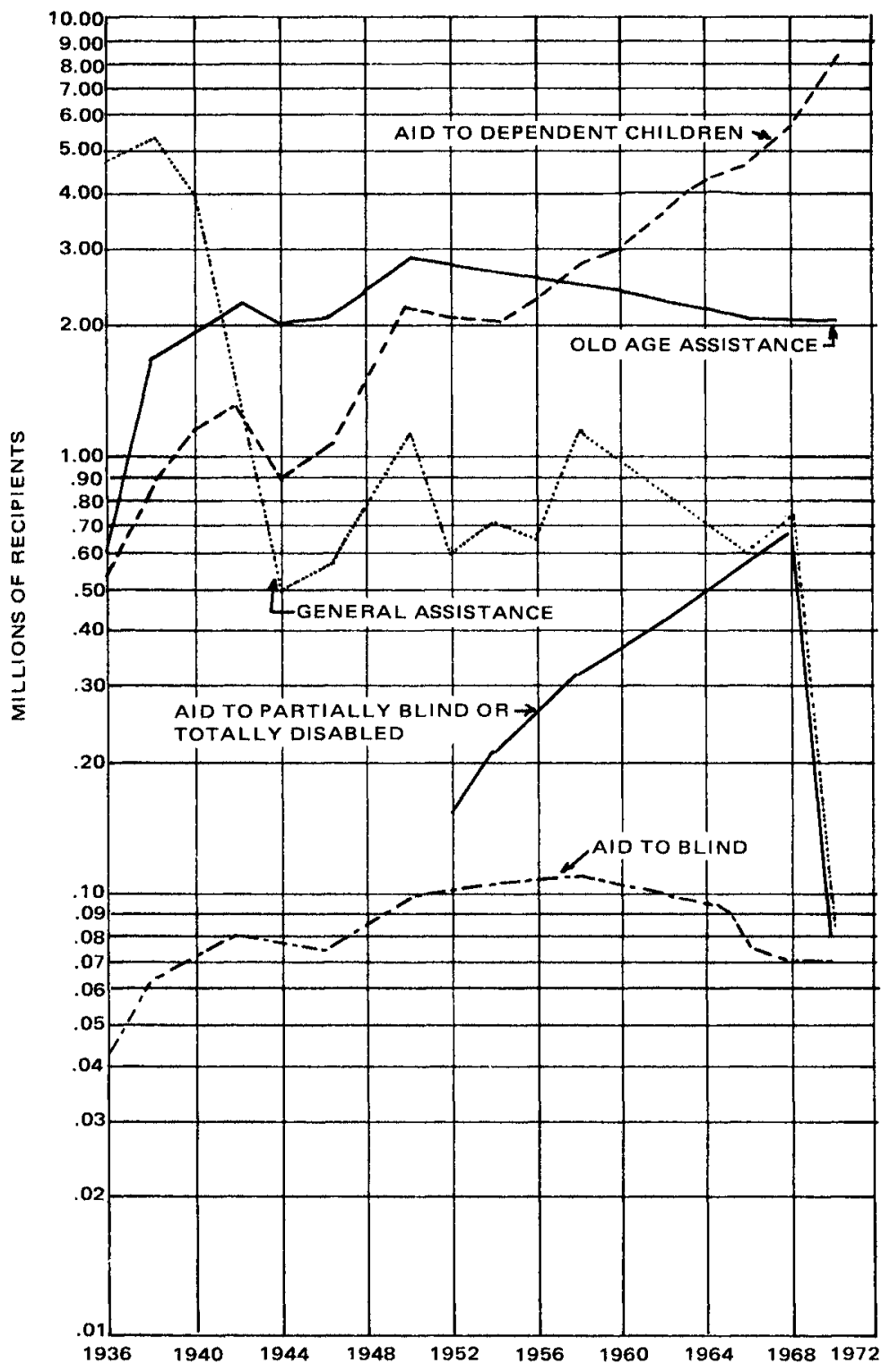

anless otherwise noted, all tables refer to New York City in 1970.

Source: Miscellaneous data from HEW. 
It is difficult to foretell what events future historians may decide epitomize this era. But certainly a significant candidate for the honor must be the budgetary crossover of 1970 , when for the first time New York City's expenditures on welfare exceeded the fast-growing education budget. ${ }^{4}$ For the nation as a whole, money payments to recipients of welfare by fiscal year 1970 were over $\$ 14$ billion. $^{5}$

\section{THE GROWTH OF WELFARE}

In Exhibit 1.1 some of the gross figures on the increase in welfare recipients are indicated. From 1960 to 1970 the absolute level of population went from $179,325,671$ to $203,184,772$; the level of welfare recipients meanwhile rose from $7,098,000$ to $10,603,100$, or from 4 percent of the population to 5.2 percent. In 1936 in the depths of the Depression, the total number of categorical (i.e., excluding General Assistance) welfare recipients was under two million.

Would the proportions of our population on the welfare rolls in 1936 have been the same if the program had been administered and the categories of welfare defined as they have been in more recent years? Is there something novel about the current life styles of the population of our country or is it merely that our society has matured to the point where it will no longer abandon people to poverty and hunger as it did in the thirties? Does the striking growth in Aid to Dependent Children (ADC) reflect a basic change in familial relationships or is it that the State only now is beginning to take responsibility for problems that were always present but remained part of the invisible society of the poor? These issues remain to be more thoroughly researched. The fact is, however, that the number of welfare recipients is growing.

The national welfare load in 1960 consisted of 6.8 million people and in $1965,8.2$ million. From 1965 to 1970 , it increased by more than 50 percent, in contrast to the first five years of the $1960 \mathrm{~s}$, in which the increase was approximately 20 percent. And the greater part of this increase is in the categorical forms of welfare. ${ }^{6}$ There has been an increase in the inclusiveness of categories and in the proportion of people covered by these categories as contrasted with municipal assistance.*

The number of people publicly assisted in New York City has risen more sharply than in the rest of the nation. In 1948 the city had a quarter of a million welfare recipients; by 1965 the figure had risen to a half million. In 1965 one in 16 New Yorkers and one in nine children under 18 were receiving some form of public assistance. In 1960 only one in 24 residents and one in 16 children were welfare recipients. The

${ }^{*}$ See Appendix 1.2 for definition of welfare categories. 
50 percent increase in New York City's welfare load in the 1960-1965 period was more than three times Chicago's increase (16 percent) and more than twice Philadelphia's increase ( 25 percent).

The half million New Yorkers on welfare in 1965 grew to threequarters of a million persons by 1967. Between 1948 and 1965 the welfare rolls increased by a quarter of a million recipients. By 1968 the rolls had grown by another quarter of a million (Exhibit 1.2). ${ }^{7}$ New York City's welfare load in early 1972 was over 1.3 million, with the net number of additional recipients running between 5,000 and 15,000 each month. Why did this growth occur?

\section{EXHIBIT 1.2}

\section{AVERAGE ANNUAL NUMBER OF NEW YORK CITY WELFARE RECIPIENTS BY CATEGORY}

\begin{tabular}{|c|c|c|c|c|c|c|}
\hline \multirow{2}{*}{ YEAR } & \multicolumn{6}{|c|}{ CATEGORY OF WELFARE } \\
\hline & Totals & $\begin{array}{l}\text { Home } \\
\text { Relief }\end{array}$ & $\begin{array}{l}\text { ADC } \\
\text { TADCa }\end{array}$ & $\begin{array}{l}\text { Old Age } \\
\text { Assistance }\end{array}$ & $\begin{array}{l}\text { Aid to } \\
\text { Blind }\end{array}$ & $\begin{array}{c}\text { Aid to } \\
\text { Disabled }^{b}\end{array}$ \\
\hline $\begin{array}{l}1941 \\
1942 \\
1943 \\
1944 \\
1945 \\
1946 \\
1947 \\
1948 \\
1949 \\
1950 \\
1951 \\
1952 \\
1953 \\
1954 \\
1955 \\
1956 \\
1957 \\
1958 \\
1959 \\
1960 \\
1961 \\
1962 \\
1963 \\
1964 \\
1965 \\
1966 \\
1967 \\
1968 \\
1969 \\
1970\end{array}$ & $\begin{array}{r}498,000 c \\
368,000 \\
124,000 \\
113,000 \\
122,000 \\
157,000 \\
216,000 \\
234,000 \\
264,000 \\
351,000 \\
308,000 \\
287,000 \\
256,000 \\
264,000 \\
282,000 \\
279,000 \\
295,000 \\
329,000 \\
329,000 \\
323,000 \\
346,000 \\
343,000 \\
375,000 \\
427,000 \\
484,000 \\
553,000 \\
693,000 \\
878,000 \\
1,011,000 \\
1,093,000\end{array}$ & $\begin{array}{r}389,000 \\
275,000 \\
39,000 \\
28,000 \\
25,000 \\
49,000 \\
88,000 \\
94,000 \\
110,000 \\
135,000 \\
94,000 \\
74,000 \\
55,000 \\
53,000 \\
55,000 \\
50,000 \\
52,000 \\
65,000 \\
64,000 \\
60,000 \\
53,000 \\
43,000 \\
46,000 \\
56,000 \\
67,000 \\
76,000 \\
107,000 \\
148,000 \\
155,000 \\
151,000\end{array}$ & $\begin{array}{l}43,000 \\
37,000 \\
28,000 \\
31,000 \\
43,000 \\
49,000 \\
65,000 \\
75,000 \\
86,000 \\
140,000 \\
133,000 \\
130,000 \\
120,000 \\
129,000 \\
145,000 \\
151,000 \\
166,000 \\
189,000 \\
192,000 \\
194,000 \\
230,000 \\
243,000 \\
272,000 \\
315,000 \\
361,000 \\
416,000 \\
516,000 \\
645,000 \\
753,000 \\
805,000\end{array}$ & $\begin{array}{l}55,000 \\
55,000 \\
56,000 \\
53,000 \\
52,000 \\
53,000 \\
55,000 \\
57,000 \\
60,000 \\
62,000 \\
60,000 \\
59,000 \\
56,000 \\
53,000 \\
51,000 \\
48,000 \\
47,000 \\
46,000 \\
44,000 \\
42,000 \\
36,000 \\
32,000 \\
31,000 \\
32,000 \\
33,000 \\
37,000 \\
44,000 \\
50,000 \\
58,000 \\
71,000\end{array}$ & $\begin{array}{l}2,000 \\
2,000 \\
2,000 \\
2,000 \\
2,000 \\
2,000 \\
2,000 \\
2,000 \\
3,000 \\
3,000 \\
3,000 \\
3,000 \\
3,000 \\
3,000 \\
3,000 \\
3,000 \\
3,000 \\
3,000 \\
3,000 \\
2,000 \\
2,000 \\
2,000 \\
2,000 \\
2,000 \\
2,000 \\
2,000 \\
2,000 \\
2,000 \\
2,000 \\
3,000\end{array}$ & $\begin{array}{c}9,000 \\
- \\
- \\
- \\
4,000 \\
5,000 \\
6,000 \\
7,000 \\
12,000 \\
18,000 \\
21,000 \\
23,000 \\
27,000 \\
29,000 \\
28,000 \\
27,000 \\
27,000 \\
26,000 \\
25,000 \\
24,000 \\
23,000 \\
23,000 \\
22,000 \\
22,000 \\
22,000 \\
24,000 \\
32,000 \\
43,000 \\
63,000\end{array}$ \\
\hline
\end{tabular}

Source: The City of New York, Department of Social Services, Monthly Statistical Reports, Vols, 1-31, No. 12.

a Aid to Dependent Children of Unemployed Parents (TADC) included from 1961 to 1970 only.

b Aid to Disabled not included for 1942 to 1945 .

c Figures have been rounded to the nearest thousand and therefore may not total precisely. 
The question of the dynamics of welfare growth has engendered more controversy than enlightenment. The portrayal of the typical welfare recipient runs the spectrum from an able-bodied individual who has found "a good thing" to a person incapacitated (physically or otherwise) for gainful employment. Certainly a phenomenon as widespread as this one provides ample opportunity to illustrate one's own prejudice with anecdotes that fit one or the other end of the range. In the course of this study some attempt will be made to define statistically the varied characteristics of the people on present-day welfare rolls. In this section, however, only a few of the reasons that have been advanced will be explored.

\section{EMPLOYMENT OPPORTUNITIES AND WELFARE}

In the 1969 report by the New York State Joint Legislative Committee appointed to revise the State Social Services Law, an analysis was made of the linkage between employment and welfare recipiency. Data unearthed by the committee showed that until 1959 new applications for family assistance followed the level of unemployment, with roughly one year's delay. When unemployment rose the number.of families needing public assistance also increased. In 1959, however, the number of cases rose on a curve independent of employment and went on rising -and continues to rise (Exhibit 1.3).

\section{EXHIBIT 1.3}

IMPORTANT SOCIAL INDICATORS

\begin{tabular}{|c|c|c|c|c|c|c|}
\hline \multirow{2}{*}{ YEAR } & \multicolumn{6}{|c|}{ INDICATORS } \\
\hline & $\begin{array}{l}\text { Gross } \\
\text { National } \\
\text { Product }\end{array}$ & $\begin{array}{c}\text { Personal } \\
\text { Income } \\
\text { (Total) }\end{array}$ & $\begin{array}{l}\text { Public } \\
\text { Assistance } \\
\text { Payments }\end{array}$ & $\begin{array}{l}\text { Unemployed } \\
\text { as Percent of } \\
\text { Civilian Labor } \\
\text { Force (UNADJ) }\end{array}$ & $\begin{array}{l}\text { Consumer } \\
\text { Price Index } \\
\text { (All Items) }\end{array}$ & $\begin{array}{c}\text { Consumer } \\
\text { Price Index } \\
\text { (Housing } \\
\text { Only) }\end{array}$ \\
\hline $\begin{array}{c}1960 \\
1961 \\
1962 \\
1963 \\
1964 \\
1965 \\
1966 \\
1967 \\
1968 \\
1969 \\
1970 \\
\text { (Feb.) }\end{array}$ & $\begin{array}{c}\$ 503.7 \mathrm{a} \\
520.1 \\
560.3 \\
590.5 \\
632.4 \\
684.9 \\
749.9 \\
793.9 \\
865.0 \\
931.4 \\
-\end{array}$ & $\begin{array}{r}\$ 401.0 \\
416.8 \\
442.6 \\
465.5 \\
497.5 \\
538.9 \\
587.2 \\
629.3 \\
688.7 \\
748.9 \\
781.5\end{array}$ & $\begin{array}{r}\$ 3.2 \\
3.4 \\
3.5 \\
3.6 \\
3.8 \\
4.0 \\
4.3 \\
4.9 \\
5.6 \\
6.6 \\
7.6\end{array}$ & $\begin{array}{l}5.5 \% \\
6.7 \\
5.5 \\
5.7 \\
5.2 \\
4.5 \\
3.8 \\
3.8 \\
3.6 \\
3.5 \\
4.7\end{array}$ & $\begin{array}{l}103.1^{\mathrm{b}} \\
104.2 \\
105.4 \\
106.7 \\
108.1 \\
109.9 \\
113.1 \\
116.3 \\
121.2 \\
127.7 \\
132.5\end{array}$ & $\begin{array}{l}103.1 \\
103.9 \\
104.8 \\
106.0 \\
107.2 \\
108.5 \\
111.1 \\
114.3 \\
119.1 \\
126.7 \\
132.2\end{array}$ \\
\hline
\end{tabular}

Source: Department of Labor, Bureau of Labor Statistics, Social Security Bulletin, Vol. 33, No. 12, December 1970.

a Monetary figures are expressed in billions of dollars.

${ }^{b}$ Consumer price index is based on 1957 to $1959=100$. 
The committee's report points to the changing nature of job opportunities between 1960 and 1970 . It cites a Department of Labor report which showed that professional and technical job opportunities for the period in question increased approximately 40 percent; jobs for skilled workers, 23 percent; and jobs for semiskilled workers only 18 percent. The Department of Labor anticipated no future increase in job opportunities for unskilled workers and a continued decrease in agricultural employment. The committee also pointed out that the proportion of adult men in the work force in surveyed slum areas of New York state dropped from 74 to 64 percent between April 1960 and November 1967. During the same period there was very little decline ( 77 to 75 percent) in the United States as a whole. ${ }^{8}$

Help-wanted advertising in New York City through 1968-1969 indicates no shortage of jobs for the able bodied. It suggests, however, that the low wage level in most of the unskilled trades has some relationship to the disinclination of the unskilled to take advantage of these "opportunities." Meanwhile New York City has ridden the crest of the national wave of increases in the cost of living. In addition, the majority of welfare growth has been accounted for, as will be discussed in detail later, by women with children and without resident husbands-the typical ADC cases. (In a small number of cases the problem may be a wifeless father with children.)

In the course of this survey, a structured probability sample of 412 welfare recipients was asked why they weren't working. In Exhibit 1.4 their reasons are given. If allowance is made for old age and for parents

\section{EXHIBIT 1.4}

\section{REASONS FOR BEING UNEMPLOYED OR ONLY PARTIALLY EMPLOYED IN 1970 BY CATEGORY OF WELFARE}

\begin{tabular}{|c|c|c|c|c|c|c|c|c|c|c|}
\hline \multirow{3}{*}{$\begin{array}{l}\text { REASON } \\
\text { NOT EMPLOYED }\end{array}$} & \multicolumn{10}{|c|}{ CATEGORY OF WELFARE } \\
\hline & \multicolumn{2}{|c|}{$\begin{array}{l}\text { Home } \\
\text { Relief }\end{array}$} & \multicolumn{2}{|c|}{$\begin{array}{l}\text { Old Age } \\
\text { Assistance }\end{array}$} & \multicolumn{2}{|c|}{$\begin{array}{c}\text { Aid to } \\
\text { Disableda }\end{array}$} & \multicolumn{2}{|c|}{$\begin{array}{l}\text { Aid to } \\
\text { Dependent } \\
\text { Children }\end{array}$} & \multicolumn{2}{|c|}{ Total } \\
\hline & No. & $\%$ & No. & $\%$ & No. & $\%$ & No. & $\%$ & No. & $\%$ \\
\hline $\begin{array}{l}\text { Laid Off } \\
\text { Acute Iliness/ }\end{array}$ & 0 & 0.0 & 0 & 0.0 & 0 & 0.0 & 4 & 2.3 & 4 & 1.3 \\
\hline Accident & 5 & 10.9 & 1 & 2.3 & 3 & 6.5 & 11 & 6.4 & 20 & 6.5 \\
\hline Chronic Illness & 24 & 52.2 & 19 & 43.2 & 40 & 87.0 & 41 & 24.0 & 124 & 40.4 \\
\hline Needed at Home & 9 & 19.6 & 1 & 2.3 & 1 & 2.2 & 110 & 64.3 & 121 & 39.4 \\
\hline Retired & 7 & 15.2 & 21 & 47.7 & 1 & 2.2 & 3 & 1.8 & 32 & 10.4 \\
\hline Other & 1 & 2.2 & 1 & 2.3 & 1 & 2.2 & 1 & 0.6 & 4 & 1.3 \\
\hline NA/DK & 0 & 0.0 & 1 & 2.3 & 0 & 0.0 & 1 & 0.6 & 2 & 0.7 \\
\hline Total & 46 & 100.0 & 44 & 100.0 & 46 & 100.0 & 171 & 100.0 & 307 & 100.0 \\
\hline
\end{tabular}

Source: Housing of Welfare Recipients Survey, 1970.

a Aid to the Disabled includes Aid to the Blind and Veterans Assistance unless otherwise noted. 
needed at home with their children, the single most frequent reason given was health problems. As the Joint Legislative Committee pointed out,

About 60 percent of our public welfare cases involved health problems-we believe strongly that many young people get sidetracked in schools and life itself by poor teeth, poor hearing, poor sight, and undiscovered internal body deficiencies. With older persons it is more serious because of years of neglect. ${ }^{9}$

To the cynic the reason of poor health frequently is viewed as a socially acceptable rationalization for inactivity. There is increasing evidence, however, to indicate that it is far more than that. ${ }^{10}$

Certainly, however, part of the welfare increase is a result of the increasing publicity given the availability of welfare as well as the decline of the historic stigma of being on the welfare rolls. In the past there have always been poor people who did not apply for welfare assistance even though they qualified. Today a higher proportion of those who qualify are aware of the programs and are receptive to them. The welfare rights organizations and the poverty program, among others, have stimulated this awareness. In later chapters welfare recipients' membership in and/or awareness of such groups will be discussed.

Until 1971 the Department of Social Services administered welfare in New York City relatively liberally. While this may have led to some growth, it is questionable whether a major amount of it can be blamed on administrative laxity. Certainly the formal and informal communication systems within a large city such as New York will make more people more aware of the benefits that they can secure than they would be aware of in less densely habitated regions. For example, in a recent survey of poverty pockets in northwest New Jersey, ${ }^{11}$ only one-third of the people who qualified for welfare were securing benefits in the relatively small cities and towns typical of the area. It is difficult to believe that the same ratio applies in New York City.

In any case, able-bodied males certainly do not dominate the welfare rolls. Increasingly, welfare expenditures are divided between the elderly (predominantly white) and primarily fatherless families on the Aid to Families with Dependent Children (ADC) program (typically minority group members).

In the nation as a whole, recipients of assistance under the ADC program increased from $3,080,000$ in 1960 to $4,457,000$ in 1965 . This increase in $\mathrm{ADC}$ recipients exceeded the total decrease in the national welfare load by 7,000; that is, ADC more than made up for the decline in recipients in other categories. By August of 1970 there were 8,659,000 ADC recipients, three-quarters of them children. This one program includes nearly 70 percent of the total number of welfare recipients. 
The growth of ADC has not occurred without interpretations. These range from causes related to slavery and the matrifocal family, to the lack of jobs for males, to the statement that welfare benefits are so generous that they outprice potential male heads of household. Determining which, if any, of these are important factors is beyond the scope of this study. It should be noted, however, that in New York City the proportion of the total Puerto Rican population receiving ADC is substantially higher than the equivalent proportion of blacks. Given the cultural patterns of strong masculine dominance among the former, it is difficult to label them subject to a matrifocal family.

The poor are not a novelty in our major cities. The older core areas' declining capacity to deal with them, however, may be relatively new. The American city is no longer a major locus of relatively unskilled factory work. Some industries which are labor intensive and demand low skills have simply been replaced by industries producing goods that respond better to capital intensification. In addition, the merchandise produced by the former type of activity is now frequently imported. In essence the United States has exported the jobs once required for its low-cost, labor-intensive merchandise. The tenementhouse industries of New York, which were once basic centers of employment for agrarian newcomers from across the ocean, have substantially disappeared. There are still some remnants scattered through the Bowery and in Chinatown, but they are relatively few. ${ }^{12}$ Again, while some of this manufacturing has moved to relatively densely populated areas in smaller communities, such as the housedress industries in the Carolinas, much of it has moved abroad. Even Puerto Rico, long the recipient of this shift, particularly in the needle trades, now faces heavy competition from such areas as Formosa, Hong Kong, Korea and other countries with relatively cheap labor.

The newcomer to the city was driven from farming by mechanization, which in cotton, for example, cut down the amount of manpower by 95 percent in one generation. Labor need diminished in equivalent proportions in many of the other areas of farm production in the United States.

But the emigrant finds little demand for his labor in the city. The limited growth in the service trades has not had much impact on his employability, since these jobs are low paid and simply not plentiful enough. As a result, the city, rather than serving as a staging ground for upward mobility, instead has become a terminus for many. In this respect, as in so many others, New York City is the classic example of the urban dilemma. While office employment has increased, blue-collar jobs are fast disappearing. Efforts to bring the poor into clerical occu- 
pations are just beginning. An estimated 40,000 jobs in the city vanished with the automation of elevators alone.

The decline of the urban job market no doubt bears some relationship to the fact that three-fourth of all welfare recipients in New York state are on the New York City welfare rolls, but it does not explain why one out of every ten recipients in the United States lives in New York City.

\section{BACKGROUND OF THE STUDY}

The purposes of this study are several. Initially it was designed as an extension of a research effort on the economics of New York City's housing stock. ${ }^{13}$ In the course of that study, which involved substantial interviews with landlords, and the development of data on operating costs and a number of other variables, it became evident that the larger the proportion of welfare tenants in a particular building, the poorer the quality of the structure. This held even when variables such as race of tenants, age and experience of landlord, scale of landlord holdings, rent levels, rent increases over time, profitability, and repairs and maintenance costs were controlled.

The proportion of welfare tenancy, in terms of statistical analysis, is obviously tied to the maintenance variable. The primary objective, we felt, was to get a stronger feeling for the housing market from the viewpoint of the welfare tenant. How does he find housing? What does he (or society) get for his/their dollars? How and how well does the market work? And are there some obvious areas of reshaping that should be undertaken?

The proportion of welfare money that goes toward rent payments is enormous. In 1968, according to a study by the Department of Housing and Urban Development (HUD), welfare clients spent $\$ 1.1$ billion for housing. This figure is identical with the total amount budgeted in 1969 for all kinds of social and rehabilitation services. It was also about onethird of the amount budgeted for cash assistance in all public assistance categories. ${ }^{14}$ In 1969 the New York State Board of Social Welfare estimated that welfare rents in New York state alone amounted to substantially over $\$ 400$ million. While the quality of environment enjoyed by welfare recipients will be discussed in detail later, it is undoubtedly true that these dollars frequently do not buy adequate housing. Is this simply a matter of economics? Of prejudice? What variables enter into the poor quality of welfare housing?

The statistical relationship between poor maintenance and welfare tenancy is subject to a host of interpretations. It may be that welfare recipients are accepted as tenants only when a building is on its last legs; or that, in the very act of letting in welfare recipients, owners feel 
this is the end of the structure and therefore reduce maintenance (the self-fulfilling prophecy); or that welfare recipients are destructive to the buildings they live in. And this is by no means an exhaustive list.

But housing and attitudes toward housing cannot be viewed in isolation. It is essential that they be placed within the context of the interests, worries and aspirations of welfare recipients. A number of psychological measures, therefore, are applied to provide the rough outlines of this broader framework. Much of the material which follows explores these relationships.

\section{HOUSING'S LINKAGE TO SOCIAL TRAUMA}

A generation ago a heading like the preceding would have been redundant. The social thinkers of the 1930s, reared on Jacob Riis' vision of the slum as the generator of all social ills, ${ }^{15}$ completely accepted this relationship. Doing away with the slums was equated with victory over vice, crime, ill health, educational underachievement and most of the other social problems of the day.

The battle today, at least in some places, has shifted from improving the absolute quality of housing - the reduction of very severe overcrowding, providing more adequate toilet facilities and the like-to one of comparative quality of housing. Does the discontinuity between the housing available to the poor and the welfare recipient, and the much promulgated middle-class ideal-at least that vision of it presented in television and the popular media-generate social problems?

Resolving the older problem is simply a matter of maintenance and economics. Resolving the second is much more difficult. In any case the literature is far from adequate. Alvin Schorr puts it very bluntly:

...it is said that poor housing causes poverty. Research has been largely confined to the statistical correlations which fail to demonstrate a causal relationship. When poor people moved into decent housing, property deteriorated, the public concluded that poverty caused poor housing rather than the other way around. On the whole, research has abandoned the question of this unsatisfactory point. 16

In any case, much public discussion suffers from the kind of thinking exemplified as "I'm not a horse, but if I were a horse how would I feel living in that stable?" We have attempted to avoid this pitfall here. While certain measurements of housing quality are determined from objective observation, it is our belief that not only the actual state of housing but the vision of that reality determines consumer satisfaction and response. 
Certainly, the absolute quality of housing occupied by welfare recipients, as will be detailed later, still leaves much to be desired. When a male head of household who is presently on Home Relief was asked what he wanted most in a place to live, his answer was very modest: "A decent gas stove, running hot water, a clean place, more room, and no roaches and mice." When asked about his present apartment, he answered: "The place isn't fit for cattle to live in. People set fires right outside of your door and the place isn't fit to live in."

Would they still set fires if the apartments were better? That is a very important question. One of the difficulties in answering it, however, is the combination of indignation about a particular apartment and the lack of safety and overall deterioration in the area. It is very difficult to distinguish between the impact of people's problems, maintenance problems and societal problems. In the next chapter, we will discuss the methodology used in this study to clarify some very limited aspects of these factors.

Chapter 3 is concerned with the characteristics of welfare recipients: how long they have lived in New York, where they come from, their ages, household configuration, education and employment history.

In Chapter 4 attention is turned to the types of housing accommodations presently utilized by welfare recipients. Is there such a thing as a welfare building-a building largely or solely occupied by welfare recipients? If so, are a significant number of New York City's welfare recipients so housed and is this an increasing trend? How can the quality of accommodations best be appraised? How do welfare recipients find their apartments, and once settled how long do they stay? How does the Department of Social Services affect recipients' search for housing? Data on public housing's provision of accommodations for welfare recipients, as well as the function and significance of hotel residency, are also presented in this chapter.

Chapters 5 and 6 revolve around the welfare recipient's attitudes toward his housing and its location, his hopes, fears and general outlook toward life. What is the level of satisfaction with the housing accommodations? What kind of things are wanted that are not presently available? What determines satisfaction with housing-area, garbage collection, apartment maintenance, building maintenance, safety, actual apartment configuration?

Chapter 6 focuses on the personal hopes and fears of welfare recipients, using the Cantril Self-Anchoring Striving Scale technique. We have compared responses secured in the course of this study of welfare recipients with equivalent measures taken from a variety of groups. 
Chapters 7 and 8 take up the costs of welfare housing; rents, operating expenses and profitability. Do welfare rents vary significantly as a function of ethnicity or category of welfare? If any alternate means of housing welfare recipients are used, much more intensive analyses of the present economics of welfare housing will be required. A step in this direction is taken in Chapter 8 which contains analyses of expenses, repairs and maintenance, and the relationship of profitability to welfare housing. Projections of alternate uses for the presently expended in welfare rents are discussed as well as alternative approaches to future funding. Particular emphasis is placed on the problems of potential alternative financing.

The final chapter of the study is devoted to a summary of the findings and their policy implications.

\section{NOTES}

1. United State Department of Health, Education and Welfare, Public Assistance Statistics (Washington, D.C., August 1970).

2. Beatrice Ida Vulcan, Fair Hearings in the Public Assistance Programs of the New York City Department of Welfare, unpublished doctoral dissertation (New York: School of Social Work, Columbia University, 1972) p. 316.

3. Bureau of Labor Statistics Report 375, C.P.S. Series P-23, No. 29.

4. Is the New York experience unique or a forecast of things to come? Certainly a similar situation cannot be far off in Boston where one out of every five residents is on welfare. Even some of the older suburbs are fast approaching the New York level of expenditures, though the pattern is obscured by variations in funding procedures. See George Sternlieb et al., The Zone of Emergence (New Brunswick, New Jersey: Transaction Books, 1972).

5. National Center for Social Statistics, Expenditures for Public Assistance Payments 1936-1970 (Health, Education and Welfare, July 6, 1971).

6. See Appendix 1.2 for more on growth rates.

7. Public Welfare in Transition: The Challenge/Change in Communities, Concepts, Cost. Report of the Joint Legislative Committee to Revise the Social Services Law of New York State, 1969.

8. Joint Legislative Committee, p. 19.

9. Ibid., p. 47.

10. On the incidence, for example, of serious anemia, see George Sternlieb and Mildred Barry, Newark: Social Needs and Social Resources (Rutgers, 1967), p. 99. For comparable data see Jack Chernick, Bernard P. Indik and George Sternlieb, Newark-Population and Labor Force (Rutgers, 1968), p. 16.

11. The unpublished study was conducted by the Rutgers Center for Urban Policy Research in conjunction with the Northwest New Jersey Community Action Program, Inc., in 1971. 
12. For a good description of the tenement-house industries in New York City at an earlier date, see Abraham Cahan, The Rise of Jacob Levinsky: a Novel (New York: Harper, 1917) and Moses Rischlin, The Promised City (New York: Corinth Books, 1964). For an analysis of the shift of employment opportunities in New York City, see Max Hall, ed. Made in New York (Cambridge, Mass.: Harvard University Press, 1959).

13. George Sternlieb, The Urban Housing Dilemma (New York: Housing Development Administration, 1970).

14. U.S. Department of Health, Education and Welfare, The Role of Public Welfare in Housing: A Report to the House Committee on Ways and Means (Washington, D.C., 1969), p. 8. It should be noted that a later estimate by HEW which included rents paid by Social Security recipients amounted to $\$ 9$ billion. See HEW and Housing (unpublished memorandum, September 13, 1970).

15. Jacob Riis, How the Other Half Lives: Studies Among The Tenements of New York (New York: Charles Seribner's Sons, 1890).

16. Alvin Schorr, Explorations and Social Policy (New York: Basic Books, 1968), pp. 272-286. For a review of the literature, see Nathan Glazer, "Housing Problems and Housing Policies" in The Public Interest (Spring 1967). 